\title{
Immunolocalisation of cytokeratins in the normal and neoplastic human pituitary gland
}

\author{
J W IRONSIDE,* J A ROYDS, $\ddagger$ A A JEFFERSON, $\dagger$ W R TIMPERLEY* \\ From the *Departments of Neuropathology and Neurosurgery, $\dagger$ Royal Hallamshire Hospital, and the \\ Department of Biochemistry, University of Sheffield, $\ddagger$ Sheffield, UK
}

SUMMARY Cytokeratins were studied by immunocytochemical techniques at light and electron microscopy on 12 normal pituitary glands, 30 pituitary adenomas and three craniopharyngiomas. The results are presented in relation to clinical and biochemical features and new information on the subcellular localisation of cytokeratins in pituitary cells is discussed.

Intermediate filaments (also known as $10 \mathrm{~nm}$ filaments) are proteins which form part of the cytoskeleton in almost all vertebrate cells. ${ }^{1}$ Biochemical and immunological analyses have enabled classification into five main groups, of which the cytokeratin class is normally found in epithelial cells of both keratinising and nonkeratinising types. ${ }^{23}$ In man, 19 different cytokeratin polypeptides have been identified with molecular weights ranging from $40,000-70,000$ daltons. $^{2}$ In squamous epithelia these polypeptides may aggregate into bundles with other proteins to form keratin tonofilaments. ${ }^{1}$ Antibodies raised against cytokeratin polypeptides have been usefully employed in diagnostic immunocytochemistry. ${ }^{13-6}$ Cytokeratins are known to occur in cells of the normal pituitary gland and several polypeptide species have recently been described in some classes of pituitary adenomas. ${ }^{7-9}$ We report the results of a light and electron microscopic immunocytochemical investigation of cytokeratins in the normal fetal and adult human pituitary gland and in pituitary neoplasms, comparing the immunocytochemical findings with the results of clinical and endocrinological studies.

\section{Materials and methods}

Normal pituitary glands were obtained at necropsy from five male and five female patients (age range 18-67 years) who had died suddenly with no clinical history of pituitary or other endocrine dysfunction. Normal fetal pituitary glands

Address for reprint requests: Dr J W Ironside, Department of Neuropathology, Royal Hallamshire Hospital, Glossop Road, Sheffield S10 2JF, UK.

Received 25 February 1986.

Accepted 1 April 1986 were obtained at necropsy from one male fetus (gestational age 27 weeks) and one female fetus (gestational age 38 weeks) who were anatomically normal stillbirths following spontaneous abortions. Surgically resected tissues were obtained from 30 pituitary adenomas from 13 male and 17 female patients (age range 18-72 years) and three craniopharyngiomas from one female and two male patients (age range 16-32 years). Material for light microscopy was fixed in $10 \%$ buffered formol saline ( $\mathrm{pH} 7.0$ ) and embedded routinely into paraffin wax. Sections were cut at $5 \mu \mathrm{m}$ in thickness and stained by conventional histological techniques.

All sections for immunocytochemistry were dewaxed and endogenous peroxidase activity blocked using $0.5 \%$ hydrogen peroxide in methanol for 10 minutes. The sections were then incubated in $0.05 \%$ trypsin $/ 0.1 \%$ calcium chloride $(\mathrm{pH}$ 7.8 ) at $37^{\circ} \mathrm{C}$ for up to 30 minutes. Antisera dilutions and all washes were carried out in TBS-buffered saline $(5 \mathrm{mmol}$ Tris $\mathrm{HCl}$ [pH 7.6]) plus $137 \mathrm{mmol} \mathrm{NaCl}$. Staining for anterior pituitary hormones (Growth Hormone [GH], Prolactin [PR], Adrenocorticotrophic Hormone [ACTH], Thyroid Stimulating Hormone [TSH], Follicle Stimulating Hormone [FSH], and Luteinising Hormone [LH]) were performed by the peroxidase-antiperoxidase (PAP) technique ${ }^{10}$ using a monospecific polyclonal antibody for each hormone (Dakopatts Pituitary Kits K514 and K517, Mercia Brocades Ltd, Weybridge, Surrey). Staining for high subunit molecular weight cytokeratins was performed by the PAP technique ${ }^{10}$ using a polyclonal antibody (Dakopatts A575, Mercia Brocades Ltd, Weybridge, Surrey) at a dilution of 1:200. Negative controls for all polyclonal antibodies were performed using normal rabbit serum. An indirect immunoperoxidase technique was used to demonstrate low subunit molecular weight cytokeratins using the monoclonal antibody PKK1 (Lab Systems (UK) Ltd, Uxbridge, Middlesex) as follows:

1 Incubation with monoclonal antibody at 1:200 dilution (30 minutes).

2 Rinse twice in TBS.

3 Incubation with rabbit antimouse peroxidaseconjugated IgG (Dakopatts, Mercia Brocades Ltd, Weybridge, Surrey) at a dilution of 1:100 (30 minutes). 
4 Three washes in TBS (each 3 minutes).

5 The reaction product was visualised using $0.05 \%$ diaminobenzedine tetrahydrochloride and $0.01 \%$ hydrogen peroxide in $50 \mathrm{mmol}$ Tris $\mathrm{HCl}$ buffer $(\mathrm{pH} \mathrm{7 \cdot 6})$.

All the PAP stained sections were counterstained in haematoxylin before being dehydrated and mounted for microscopic examination. Serial sections were cut from the normal pituitary glands and alternate sections stained for cytokeratins and each of the six anterior pituitary hormones. Sections of normal human skin were used as positive controls for high subunit molecular weight cytokeratins and sections of a human basal cell carcinoma were used as positive controls for low subunit molecular weight cytokeratins. Cytokeratin immunoreactivity for each neoplasm was recorded on a scale from 0 (absent) to +++ (abundant) without prior knowledge of the results of hormone immunocytochemistry.

Material from surgically resected pituitary neoplasms was fixed for electron microscopy in $2 \%$ glutaraldehyde and post fixed in osmium tetroxide before processing into Emix (EMscope Labs Inc, Ashford, Kent). $1 \mu \mathrm{m}$ sections were cut and stained with Toluidine Blue. Ultrathin sections from selected areas were cut and stained with Lead Citrate and Uranyl Acetate. For immunoelectron microscopy ultrathin sections of embedded tissue were cut and mounted on copper grids. An immunogold technique was performed as follows:

1 Wash in $10 \%$ hydrogen peroxide (20 minutes).

2 Three washes in distilled water (10 minutes each).

3 Incubate in normal goat serum diluted 1:30 in 70 mmol TBS ( $\mathrm{pH} 7 \cdot 2$ ) containing $0.2 \%$ bovine serum albumin (30 minutes).

4 Incubate overnight at $4^{\circ} \mathrm{C}$ in monoclonal antibody PKKL in a 1:50 dilution in TBS (pH 7.2) containing $0.2 \%$ bovine serum albumin.

5 Two washes in TBS (pH 7.2) containing $0.2 \%$ bovine serum albumin (each 10 minutes).

6 Incubate in TBS ( $\mathrm{pH} \mathrm{8.6)}$ containing $1 \%$ bovine serum albumin (10 minutes).

7 Incubate in goat antimouse IgG G20 (Janssen Pharmaceutica, Beerse, Belgium) diluted 1:5 in TBS ( $\mathrm{pH} 8.6$ ) containing $1 \%$ bovine serum albumin at room temperature ( 80 minutes).

8 Wash in TBS (pH 8.6) containing $1 \%$ bovine serum albumin ( 5 minutes).

9 Two washes in TBS (pH 7.2) containing $0.2 \%$ bovine serum albumin (each 10 minutes).

10 Two washes in distilled water (each 10 minutes).

11 Lightly stain in Uranyl Acetate and Lead Citrate (approximately 5 minutes).

Negative controls were performed by both omitting the primary antibody and substituting a monoclonal antibody to glial fibrillary acidic protein (GFAP) (Sanbio BV, Netherlands) in the method above. GFAP is known not to occur in hormone secreting cells of the adenohypophysis. ${ }^{11}$

The grids were examined and photographed on a Corinth AEl electron microscope. The density of immunolabelling with PKK1 over the cytoplasm, fibrous bodies and nucleus in sparsely granulated $\mathrm{GH}$ adenomas was calculated by the method of Bendayan et $a^{12}$ and compared with controls for each case.
Table 1 Pathological diagnosis of the pituitary neoplasms following immunocytochemistry and electron microscopy

\begin{tabular}{ll}
\hline Diagnosis & Number of cases \\
\hline GH adenoma & 7 \\
PR adenoma & 9 \\
ACTH adenoma & 4 \\
TSH adenoma & 2 \\
FSH/LH adenoma & 3 \\
Nonsecretory adenoma & 4 \\
Oncocytoma (nonsecretory) & 1 \\
Craniopharyngioma & 3 \\
Total & 33 \\
\hline
\end{tabular}

\section{Immunoblots}

Fresh normal human anterior pituitary tissue obtained at necropsy was stored at $-70^{\circ} \mathrm{C}$ until just prior to use. The tissue was homogenised in electrophoresis sample buffer $(0 \cdot 25 \mathrm{M}$ Tris $\mathrm{HCl}, \mathrm{pH} 6.8,1 \% \mathrm{SDS}, 20 \%$ glycerol, $1 \%$ mercaptoethanol), boiled for 5 minutes and any insoluble material removed by centrifugation. The soluble extract was applied to a 9\% SDS-polyacrylamide gel for electrophoresis. ${ }^{13}$ Molecular weight markers of $M_{r}$ 25,700-76,000 (BDH Chemicals Ltd) were run simultaneously. Transfer of polypeptides to nitrocellulose sheets was carried out overnight by the method of Towbin et al. ${ }^{14}$ The blot was incubated with the monoclonal antibody PKK1 at a dilution of 1:250 and the peptides identified by the antibody were visualised by the alkaline phosphatase method of Blake et al. ${ }^{15}$

\section{Clinical studies}

The site and approximate size of each neoplasm was recorded at surgery. Anterior pituitary hormones were measured pre-operatively in the serum of all patients by radioimmunoassay. Patients with ACTH secreting adenomas had urinary free cortisol estimations performed by radioimmunoassay on preoperative 24 hour specimen collections. Fresh tissue from each pituitary adenoma was sent to Dr Keith Mashiter, Hammersmith Hospital, London, for cell culture and pituitary hormone radioimmunoassay of culture supernatant.

\section{Results}

\section{Light microscopy}

The results of immunocytochemical staining for anterior pituitary hormones on the $\mathbf{3 0}$ pituitary adenomas are listed in table 1 . Two of the growth hormone adenomas contained cells with immunoreactive prolactin and three of the prolactin adenomas contained cells with immunoreactive growth hormone, but in each case the number of cells containing the secondary hormone was small (approximately 5\%). The immunocytochemical diagnosis was confirmed in each case by electron microscopy using the diagnostic criteria of Kovacs, Horvath and McComb. ${ }^{16}$ Electron microscopy also enabled the diagnosis of oncocytoma to be made in one case. Staining for anterior pituitary hormones in the three intrasellar cranio- 


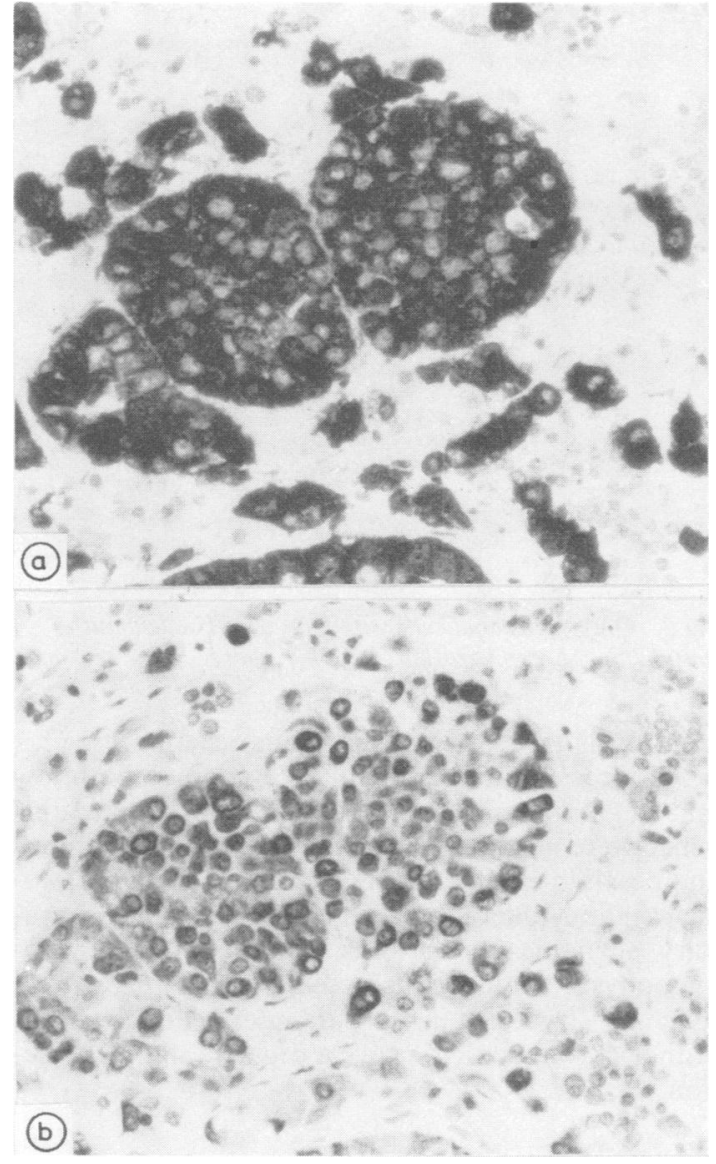

Fig 1 (a) ACTH cells in a normal adult pituitary demonstrated by the PAP technique using an antibody to $A C T H$. (b) An adjacent serial section to fig la stained by an indirect immunoperoxidase technique for cytokeratins using antibody PKK1. Most of the ACTH cells contain cytokeratins $(\times 210)$.

pharyngiomas was negative. The distribution of the various hormone containing cells in the normal adult and fetal pituitaries was in accordance with previously published observations. ${ }^{1718}$

Low subunit molecular weight cytokeratins were detected in many cells in the normal adult and fetal adenohypophysis using the monoclonal antibody PKK1. Comparison with adjacent sections stained for anterior pituitary hormones showed that the cells containing the most immunoreactive cytokeratins were of the growth hormone and prolactin types. Staining was usually present throughout the cytoplasm of these cells, but in some GH cells appeared to be aggregated in the centre of the cell adjacent to the nucleus. Most of the ACTH cells also contained low

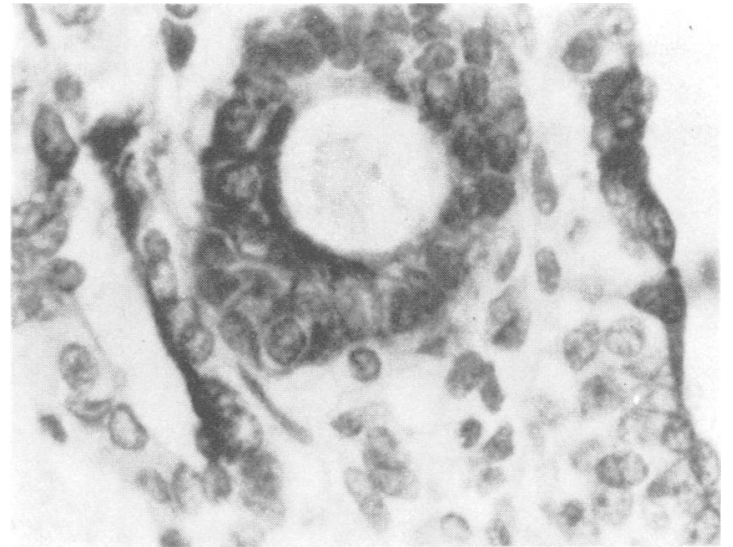

Fig 2 Follicular structures in the pars intermedia of a fetal pituitary contain low $M_{r}$ cytokeratins $(P K K 1 \times 600)$.

subunit molecular weight cytokeratins but showed a variable intensity of cytoplasmic staining (fig la and b). None of the cells containing FSH, LH and TSH appeared to contain low subunit molecular weight cytokeratins in the cytoplasm. Positive staining was seen in occasional follicular structures in the adenohypophysis containing colloid-like material and within the flattened cuboidal epithelium lining cystic structures within the pars intermedia (fig 2). The remainder of the pars intermedia and neurohypophysis showed no staining.

The results of immunocytochemical staining for cytokeratins in the pituitary neoplasms are listed in table 2 . In the $\mathrm{GH}$ adenomas, many cells contained large intracytoplasmic aggregates of immunoreactive cytokeratins located close to the nucleus (fig 3a and b). This pattern of staining was most evident in neoplasms classified as sparsely granulated $\mathbf{G H}$ adenomas on electron microscopy. A smaller number of cells within these neoplasms showed a diffusely positive staining reaction. All the PR adenomas contained cytokeratins in a variable proportion of cells, usually

Table 2 Results of immunocytochemistry for cytokeratins at light microscopic level in pituitary neoplasms with positive results recorded

\begin{tabular}{lll}
\hline & $\begin{array}{l}\text { PKKI } \\
\text { (low subunit } \\
\text { molecular weight) }\end{array}$ & $\begin{array}{l}\text { A575 } \\
\text { (high subunit } \\
\text { molecular weight) }\end{array}$ \\
\hline GH adenoma & $7 / 7$ & $0 / 7$ \\
PR adenoma & $9 / 9$ & $0 / 9$ \\
ACTH adenoma & $1 / 4$ & $0 / 4$ \\
TSH adenoma & $0 / 2$ & $0 / 2$ \\
FSH/LH adenoma & $0 / 3$ & $0 / 3$ \\
Nonsecretory adenoma & $0 / 4$ & $0 / 4$ \\
Oncocytoma & $0 / 1$ & $0 / 1$ \\
Craniopharyngioma & $3 / 3$ & $3 / 3$ \\
\hline
\end{tabular}




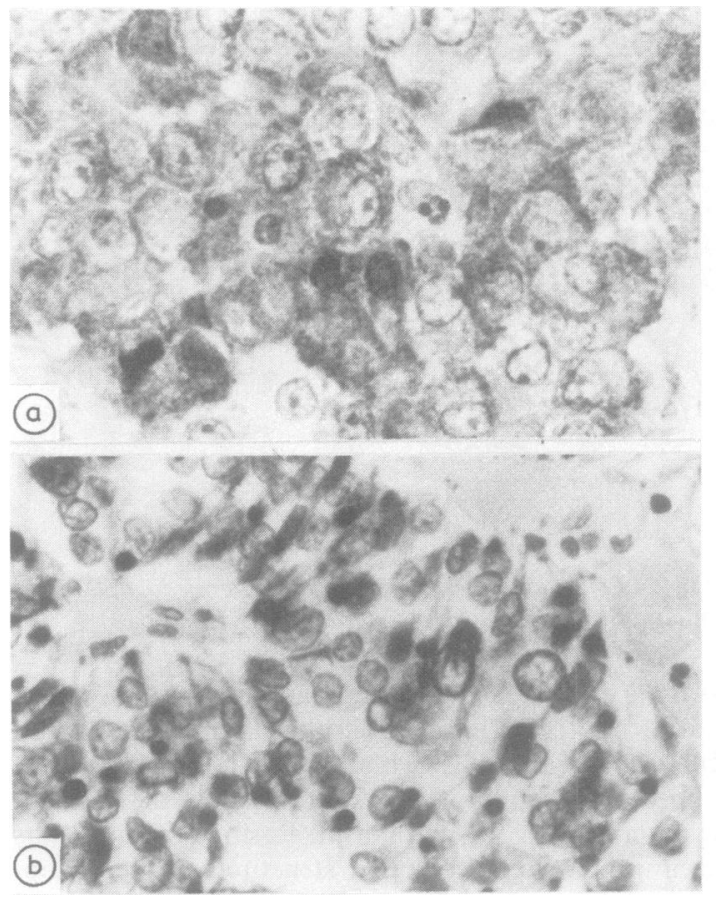

Fig 3 (a) PAP preparation for $G H$ in a sparsely granulated GH adenoma $(\times 720)$. (b) Many of the cells in the sparsely granulated $G H$ adenoma contain focal intracytoplasmic collections of cytokeratins $(P K K 1 \times 600)$.

with diffuse cytoplasmic staining (fig 4). Only one of the ACTH adenomas showed positive staining which was present in occasional cells (fig 5). The TSH, $\mathrm{FSH} / \mathrm{LH}$, and non secretory adenomas and the onco-

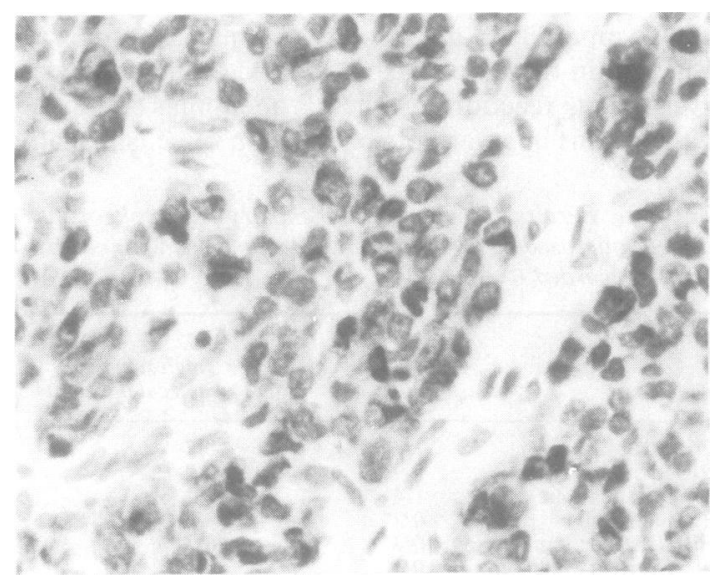

Fig 4 Diffuse cytoplasmic staining for cytokeratins is present within many cells of a PR adenoma $($ PKK1 $\times 300)$.

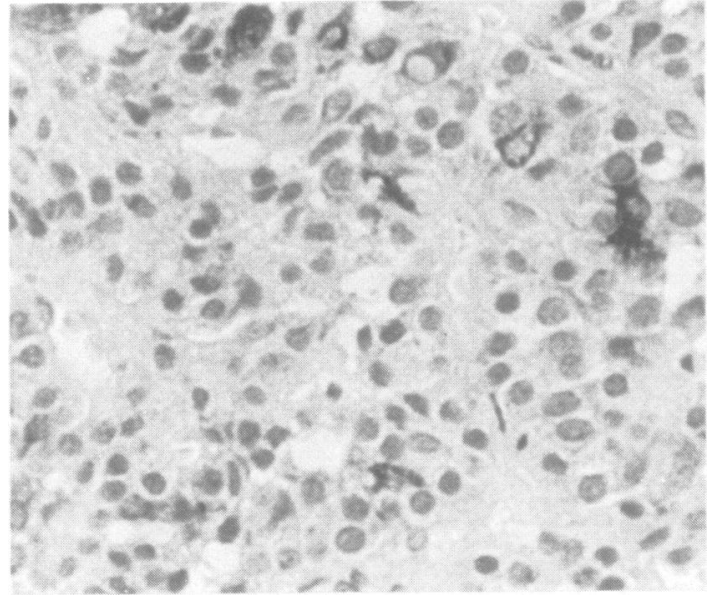

Fig 5 Only occasional cells within an ACTH adenoma contain low Mr cytokeratins $(P K K 1 \times 300)$.

cytoma all gave a negative staining reaction (fig 6).

All three craniopharyngiomas contained both low and high subunit molecular weight cytokeratins which were most readily visible in areas of squamous and basaloid epithelium (fig 7). High subunit molecular weight cytokeratins were not detected in the pituitary adenomas or in cells of the normal adenohypophysis, but were present within occasional follicular structures in the pars intermedia. The cells of the neurohypophysis gave a negative staining reaction.

\section{Electron microscopy}

Immunogold staining for cytokeratins in GH adenomas showed deposition of gold particles over

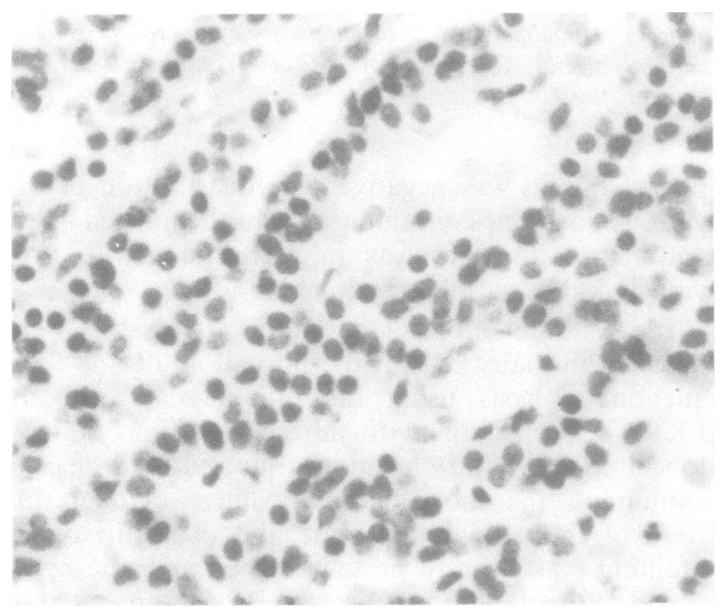

Fig 6 No cytokeratins are demonstrable in an FSH/LH adenoma $(P K K 1 \times 210)$. 


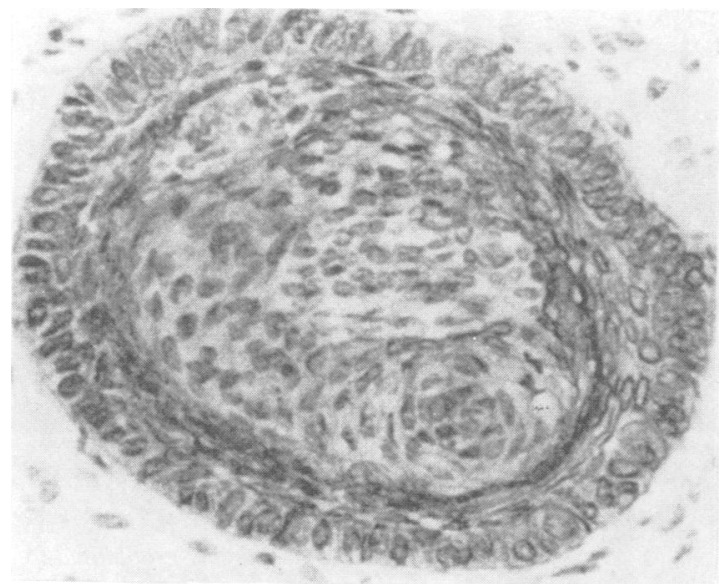

Fig 7 A strongly positive reaction is present using the $P A P$ technique for high $M$, cytokeratins in the epithelial cells of $a$ craniopharyngioma $(\times 210)$.

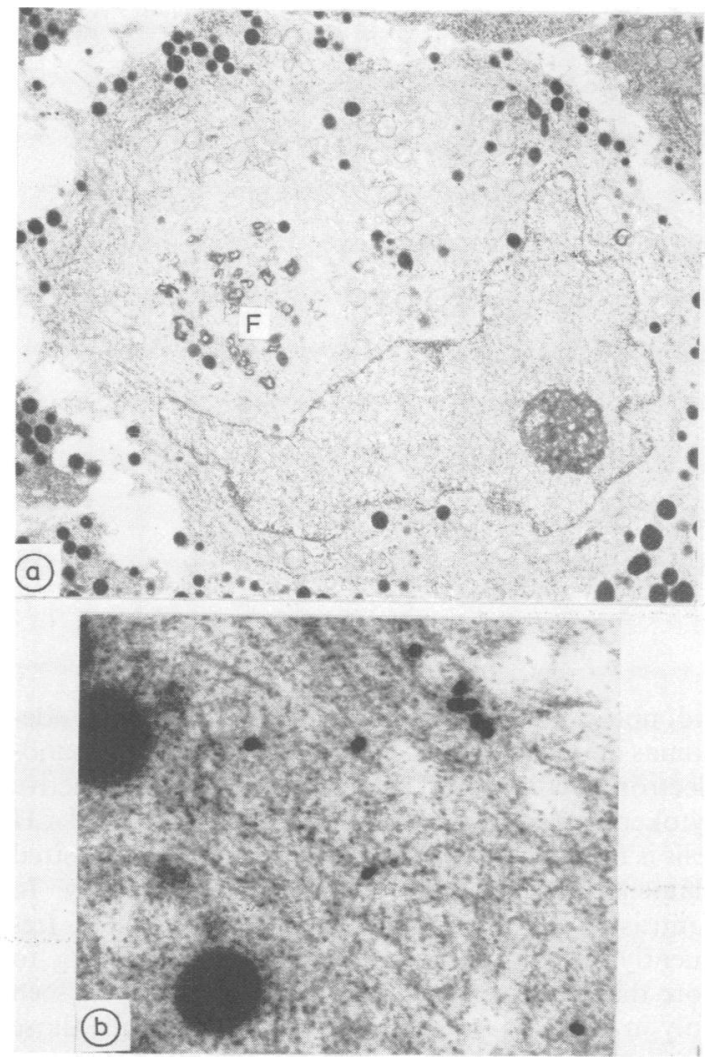

Fig 8 (a) Transmission electron microscopy reveals typical fibrous bodies $(F)$ within the cell of a sparsely granulated $G H$ adenoma $(\times 2000)$. (b) A high power photoelectronmicrograph shows deposition of gold granules along $10 \mathrm{~nm}$ filaments within a fibrous body, with no deposition over endosecretory granules (Immunogold PKKI $\times 18,000)$. the fibrous bodies in the sparsely granulated GH adenomas (fig 8a and b). Staining of centrioles, mitochondria and granules within these structures was negative. Gold deposition was also present over the heterochromatin close to the nuclear membrane and over nucleoli (fig 9). Quantitative studies confirmed the positive reaction for the $10 \mathrm{~nm}$ filaments within fibrous bodies, but also demonstrated a significant difference between the density of immunolabelling over the nucleus and cytoplasmic immunolabelling (table 3). In PR adenomas gold particles were also deposited over fibrillary structures within the cytoplasm which corresponded to $10 \mathrm{~nm}$ filaments. In the craniopharyngiomas gold particles were deposited over keratin tonofilaments and $10 \mathrm{~nm}$ filaments within the epithelial cells (fig 10). No significant gold deposition was found within the cytoplasm of cells from the remaining groups of pituitary adenomas. Staining for GFAP was negative in all the neoplasms.

\section{Immunoblots}

Four major bands of $M_{r}$ between $56 \mathrm{kD}$ and $40 \mathrm{kD}$ were identified on protein immunoblotting of normal pituitary gland using PKK1 (fig 11).

\section{Clinical studies}

The results of pituitary hormone measurements in vivo and in vitro are listed in table 4 together with the age and sex of each patient, the site and approximate size of each neoplasm and the degree of immunoreactivity for low subunit molecular weight cytokeratins. No relationship was found between the latter and the age and sex of the patients or the size and site of the neoplasms. In patients with PR adenomas there appeared to be a general inverse relationship between cytokeratin immunoreactivity in the neoplasm and hormone levels in the serum in 8/9 cases. No such trend was found for patients with GH adenomas, nor was there any correlation between cytokeratin immunoreactivity and urinary free cortisol levels in patients with ACTH adenomas. In vitro estimations of hormone productions bore no relationship to cytokeratin immunoreactivity in $\mathbf{G H}$, PR or ACTH adenomas.

\section{Discussion}

Nineteen cytokeratin polypeptides have been identified from different human epithelial tissues. ${ }^{2}$ No individual tissue has been found to contain only one variety of cytokeratin polypeptide and most epithelia show a complex mixture of various polypeptides. The monoclonal antibody used in this investigation recognises four cytokeratin polypeptides which are present in many epithelial tissues and neoplasms. ${ }^{19}$ Immunoblots of normal human adenohypophysis with PKK1 


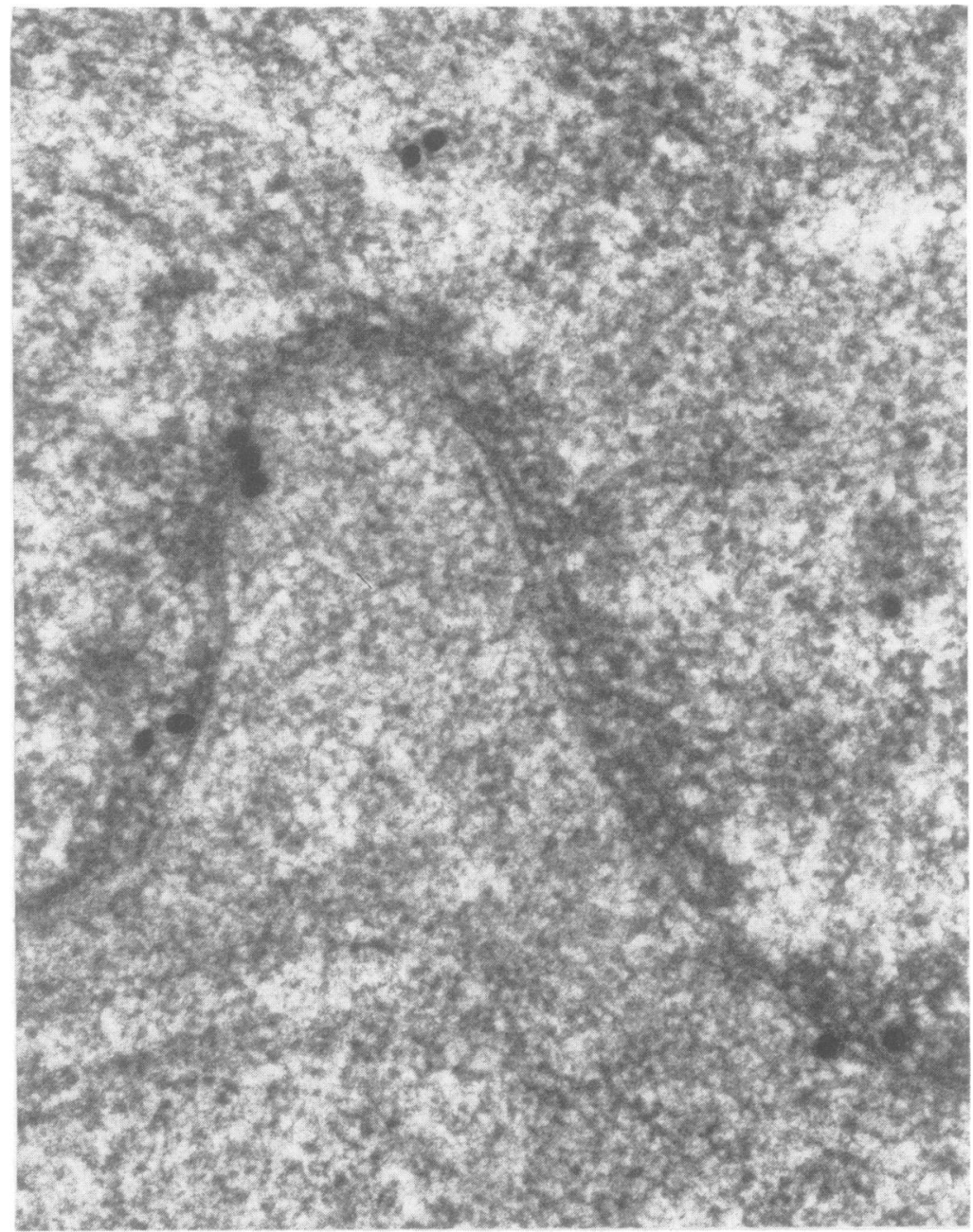

Fig 9 In a sparsely granulated GH adenoma, gold granules are present over the nucleus, confined to heterochromatin on and close to the nuclear membrane (Immunogold PKKI $\times 45,000)$.

showed four main cytokeratin polypeptides of $\mathbf{M}_{\mathbf{r}}$ 40-56kD. By comparison with other published data these probably represent cytokeratins $11,16,18$ and 19. ${ }^{2}$ The polyclonal antibody used in this study recognises high subunit molecular weight cytokeratins (predominantly $56 \mathrm{kD}$ and $64 \mathrm{kD}$ ) ${ }^{20} 21$ which were not detected in the normal adenohypophysis or pituitary adenomas. Only limited information on the specific polypeptide constituents of pituitary cytokeratins has therefore been obtained. These may be identified in future by the use of monoclonal antibodies of more restricted specificity.

The results of immunocytochemistry using PKK1 on the normal pituitary gland and pituitary adenomas are similar to those in the smaller series of Höfler $e t$ $a l,{ }^{8}$ who used an antibody of different specificity and did not examine fetal pituitary glands, TSH adenomas or oncocytomas and did not perform immunoelectron microscopy. The absence of immunoreactive cytokeratins in normal pituitary TSH, FSH and LH cells is reflected by a relative lack of intermediate sized filaments in these cells on electron microscopy. In contrast, cells secreting GH, PR and ACTH frequently contain such filaments. It is interesting to note that positive staining for cytokeratins was seen only in cells secreting peptide hormones, while those secreting glycoprotein hormones exhibited negative staining. This may reflect qualitative and/or quantitative differences in the cytokeratin polypeptide .constituents between these groups of cells which might be related to differences in intracellular hormone metabolism. ${ }^{22}$ 
Table 3 Density of immunolabelling over cellular compartments in sparsely granulated GH adenomas

\begin{tabular}{|c|c|c|c|}
\hline \multirow[b]{2}{*}{ Site } & \multicolumn{3}{|c|}{ Mean density (gold particles/ $\left.\mu m^{2}+S E M\right)$} \\
\hline & $P K K I^{*}$ & $G F A P$ & Goat Ig-gold only \\
\hline $\begin{array}{l}\text { Fibrous body } \\
\text { Nucleus } \\
\text { Cytoplasm (including organelles) }\end{array}$ & $\begin{array}{l}49.36 \pm 4.75 \\
7.09 \pm 0.53 \\
3.96 \pm 0.37\end{array}$ & $\begin{array}{l}3.99 \pm 0.41 \\
4.19 \pm 0.36 \\
4.02 \pm 0.19\end{array}$ & $\begin{array}{l}4.09 \pm 0.38 \\
3.94 \pm 0.46 \\
4.17 \pm 0.34\end{array}$ \\
\hline
\end{tabular}

*The differences within this column are significant $(\mathrm{p}<0.05$, unpaired $t$ test).

Cytokeratins have recently been demonstrated within ACTH cells exhibiting Crooke's hyaline change. ${ }^{22}$ We have been able to demonstrate cytokeratins within ACTH cells in normal adult and fetal pituitary glands, but positive staining was present in only 1/4 ACTH adenomas studied. Höfler et $a l^{8}$ have demonstrated immunoreactive cytokeratins at light microscopy in $3 / 3$ ACTH adenomas, using a monoclonal antibody reacting with intermediate subunit molecular weight cytokeratins (principally 48 kD). Neumann et $a^{22}$ have suggested that the quantity of immunoreactive cytokeratins in ACTH cells may be inversely related to levels of cortisol in the serum. No such relationship was found in this study, nor did cytokeratin immunoreactivity in ACTH adenomas correlate with the levels of urinary free cortisol in 24 hour specimen collections or ACTH production in vitro. Similarly, no relationship between cytokeratin immunoreactivity and hormone levels in vitro or in vivo was found in patients with $\mathrm{GH}$ adenomas. In patients with PR adenomas, however, there was a general inverse relationship between cytokeratin immunoreactivity and serum hormone levels in $8 / 9$ cases. This trend is of interest in view of the suggested role of intermediate filaments in hormone granule assembly and release, ${ }^{23}$ and merits further study. No relationship between hormone levels in vitro and cytokeratin immunoreactivity was found;

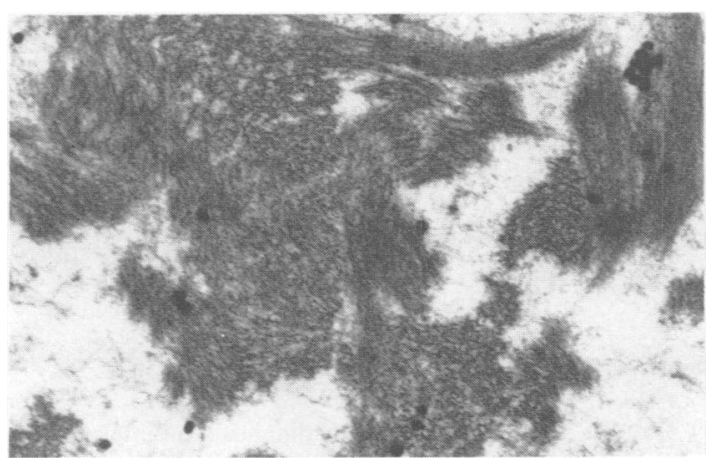

Fig 10 Deposition of gold granules is present over epithelial tonofilaments in a craniopharyngioma (Immunogold PKKI $\times 15,000)$. this would perhaps be better investigated using immunoperoxidase techniques for cytokeratins on the cells in culture.

The pattern of cytokeratin staining at light micro-

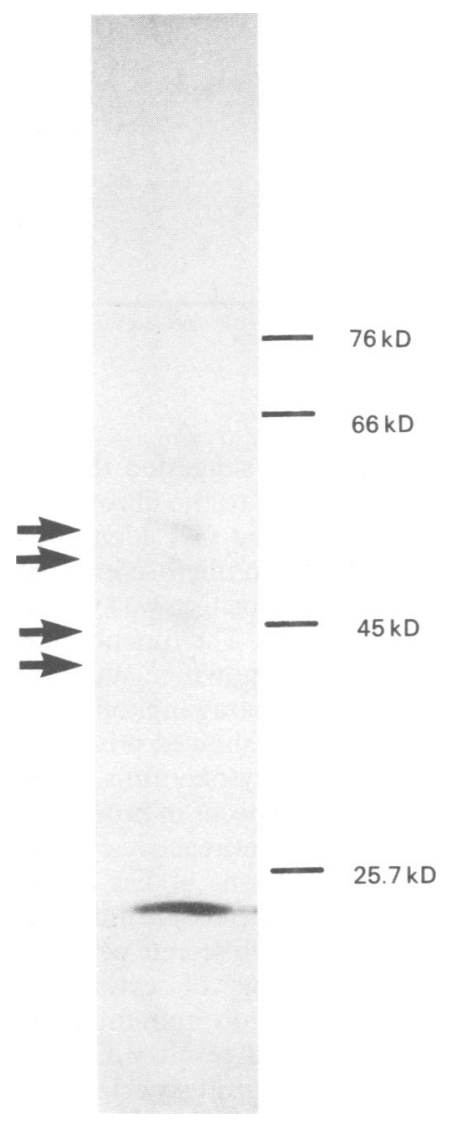

Fig 11 Polypeptide bands in extract of anterior pituitary as revealed in a PKKI Immunoblot. Four major peptides (arrows) are seen between 40-56kD. The numbers refer to the $M_{r}$ of marker proteins ( $76 \mathrm{kd}$ ovotransferrin, $66 \mathrm{kD}$ bovine serum albumin, $45 k \mathrm{D}$ ovalbumin, $25 \cdot 7 \mathrm{kD}$ chymotrypsinogen A). 
Table 4 Cytokeratin immunoreactivity (PKK1) of pituitary adenomas compared with the site and size of the lesion and hormone production in vivo and in vitro

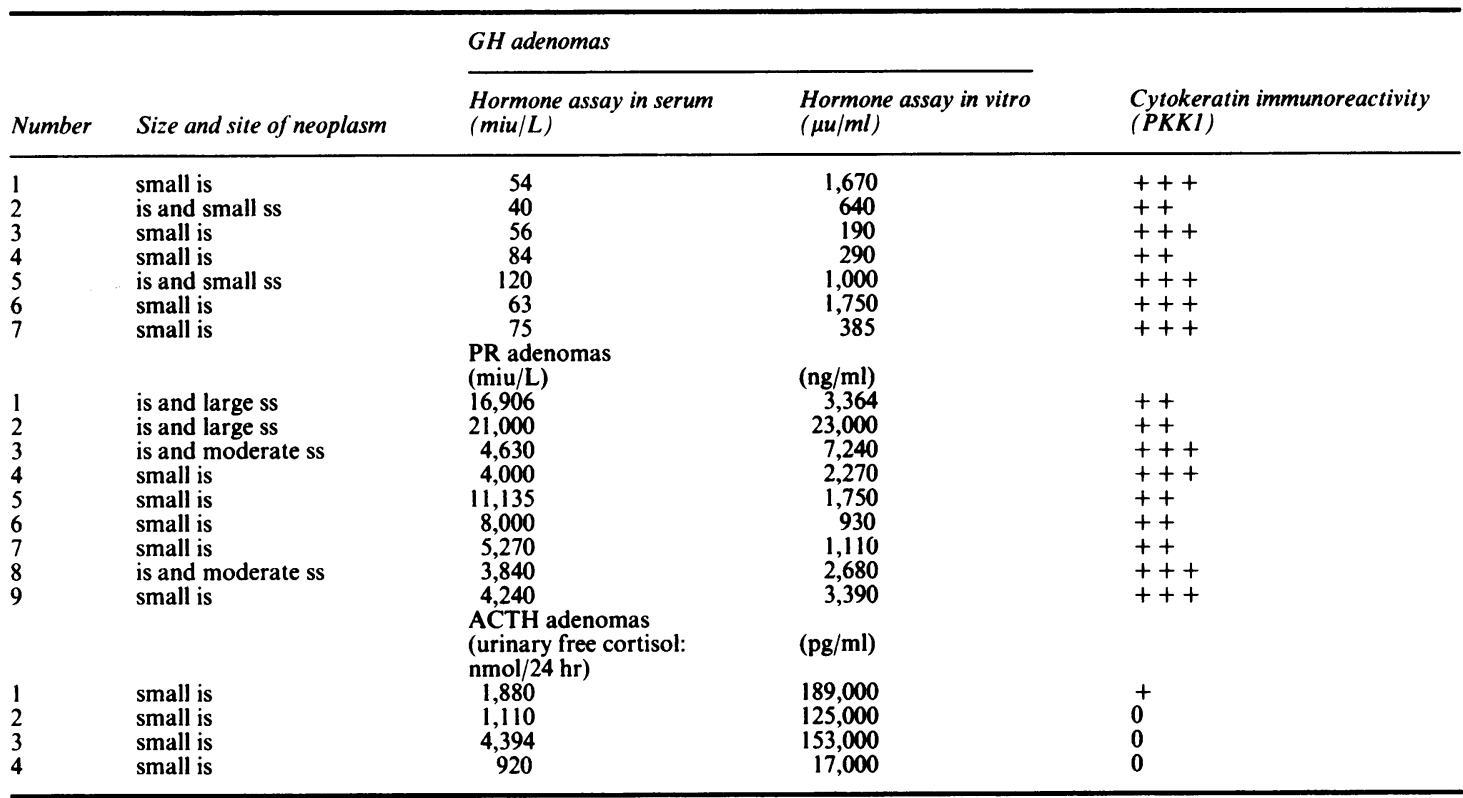

is = intrasellar.

ss $=$ suprasellar

scopy in GH adenomas suggested that cytokeratins were in some way related to the fibrous bodies occurring in sparsely granulated GH adenoma cells. ${ }^{9}$ The results of immunoelectron microscopy confirmed this suggestion since gold deposition was visualised within these fibrillary structures. The functional significance of fibrous bodies is unknown. ${ }^{23}$ We have observed fibrous bodies within a paraganglioma arising in the cauda equina which also showed positive focal intracytoplasmic staining for cytokeratins. ${ }^{24}$ Similar structures have been noted to occur in bronchial adenomas which also contain immunoreactive cytokeratins. ${ }^{25}$ It therefore seems that fibrous bodies are non specific structures which contain cytokeratins and occur in a variety of neoplasms which secrete peptide hormones.

The consistent finding of cytokeratins within nuclear heterochromatin on immunoelectron microscopy was an unexpected result which has not previously been reported in pituitary cells. A recent study on cultured hepatoma cells has demonstrated that cytokeratin polypeptides are associated with nuclear DNA at filament binding sites on or near the nuclear lamina. ${ }^{26}$ Similar associations in pituitary cells might account for the observed pattern of gold deposition on immunoelectron microscopy in this study. Traub et $a l^{27}$ have suggested that cytoskeletal proteins may have a functional relationship with DNA involving control of gene expression. Further work is required to analyse the precise nature of such cytokeratinDNA associations and to investigate their functional possibilities.

We thank Dr Keith Mashiter, Department of Medicine, Hammersmith Hospital, London for permission to use the results of hormone assays performed on cell cultures in his department, and Dr S O Waarnar, The University Medical Centre, Leiden, Holland for his generous gift of a monoclonal antibody to GFAP.

We are grateful to Mr B Barker, Mrs S Porter and Miss J Edwards for technical assistance, and to Mrs P Kirk for typing the manuscript.

Dr Royds is supported by Wellcome Trust Grant No 11353/1.5. Financial assistance from the Swann Morton Foundation is gratefully acknowledged (Special Trustees for the Former United Sheffield Hospitals Grant No 303).

\section{References}

1 Osborn M, Weber K. Tumor diagnosis by intermediate filament typing: a novel tool for surgical pathology. Lab Invest 1983;48:372-94.

2 Moll R, Franke WW, Schiller DL, Geiger B, Krepler R. The catalog of human cytokeratins: patterns of expres- 
sion in normal epithelia, tumors and cultured cells. Cell 1982;31:11-24.

3 Makin CA, Bobrow LG, Bodmer WF. Monoclonal antibody to cytokeratin for use in routine histopathology. J Clin Pathol 1984;37:975-83.

4 Ramaekers F, Huysmans A, Moesker O, et al. Monoclonal antibodies to keratin filaments, specific for glandular epithelia and their tumors. Lab Invest 1983;49:353-61.

5 Gabbiani G, Kapanaci Y, Barazzone P, Franke WW. Immunohistochemical identification of intermediatesized filaments in neoplastic cells. A diagnostic aid for the surgical pathologist. Am J Pathol 1981; 104:206-16.

6 Miettinen M, Lehto V-P, Virtanen I. Antibodies to intermediate filament proteins in the diagnosis and classification of human tumors. Ultrastruc Pathol 1984;7:83-107.

7 Asa SL, Kovacs K, Bilbao JM, Penz G. Immunohistochemical localisation of keratin in craniopharyngiomas and squamous cell nests of the human pituitary. Acta Neuropathol (Berl) 1981;54:257-60.

8 Höfler H, Denk H, Walter GF. Immunohistochemical demonstration of cytokeratins in endocrine cells of the human pituitary gland and in pituitary adenomas. Virchows Arch A 1984;404:359-68.

9 Neumann PE, Goldman JE, Horoupian DS, Hess MA. Fibrous bodies in growth hormone-secreting adenomas contain cytokeratin filaments. Arch Pathol Lab Med 1985;109:505-8.

10 Sternberger LA. Immunocytochemistry. 2nd ed. New York: John Wiley and Sons, 1979.

11 Velasco ME, Roesmann U, Gambetti P. The presence of glial fibrillary acid protein in the human pituitary gland. J Neuropathol Exp Neurol 1982;41:150-63.

12 Bendayan M, Roth J, Perrelet A, Orci L. Quantitative immunocytochemical localisation of pancreatic secretory proteins in subcellular compartments of the rat acinar cell. J Histochem Cytochem 1980;28:149-60.

13 Laemmli VK. Clearage of structural proteins during the assembly of the head of bacteriophage T4. Nature 1970;227:680-5.

14 Towbin H, Staehelin T, Gordon J. Electrophoretic transfer of proteins from polyacrylamide gels to nitrocellulose sheets: procedure and some applications. Proc Natl Acad Sci USA 1979;76:4350-4.

15 Blake MS, Johnston KH, Russell-Jones GJ, Gotschlich EC. A rapid, sensitive method for detection of alkaline phosphatase-conjugated anti-antibody on Western blots. Analyt Biochem 1984;136:175-9.

16 Kovacs K, Horvath E, McComb DJ. The fine structure of pituitary tumors. In: Motta PM, ed. Ultrastructure of Endocrine Cells and Tissues. Boston: Martinaus Nijhoff Publishers, 1984:89-113.

17 Scheithauer BW. Surgical pathology of the pituitary: the adenomas. In: Sommers SS, Rosen PP, eds. Pathology Annual Vol 19 Part 1. Norwalk, Connecticut: Appleton Century Crofts, 1984:317-74.

18 Asa SL, Kovacs K. Functional morphology of the human fetal pituitary. In: Sommers SS, Rosen PP, eds. Pathology Annual Vol 19 Part 1. Norwalk, Connecticut: Appleton Century Crofts, 1984:275-315.

19 Holthöfer H, Miettinen A, Paasivuo R, Lehto V-P, Linder E, Alfthan O, Virtanen I. Cellular origin and differentiation of renal carcinomas. Lab Invest 1983;49:317-26.

20 Schlegel R, Banks-Schlegel S, Pinkus GS. Immunohistochemical localisation of keratin in normal human tissues. Lab Invest 1980;42:91-6.

21 Dakopatts. Datasheet For Polyclonal Antikeratin Antibody A575. Weybridge: Mercia Brocades Ltd, 1985.

22 Neumann PE, Horoupian DS, Goldman JE, Hess MA. Cytoplasmic filaments of Crooke's hyaline change belong to the cytokeratin class. Am J Pathol 1984; 116:214-22.

23 Horvath E, Kovacs K. Morphogenesis and significance of fibrous bodies in human pituitary adenomas. Virchows Arch B 1978;27:69-78.

24 Ironside JW, Royds JA, Taylor CB, Timperley WR. Paraganglioma of the cauda equina: a histological, ultrastructural and immunocytochemical study of two cases with a review of the literature. J Pathol 1984; 145:195-201.

25 Berger G, Berger F, Bejui F, Bouvier R, Rochet M, Feroldi J. Bronchial carcinoid with fibrillary inclusions related to cytokeratins: an immunohistochemical and ultrastructural study with subsequent investigation of 12 foregut APUDomas. Histopathology 1984;8:245-58.

26 Ward WS, Schmidt WN, Schmidt CA, Hnilica LS. Association of cytokeratin p39 with DNA in intact Novikoff hepatoma cells. Proc Natl Acad Sci USA 1984;81:419-23.

27 Traub P, Nelson WJ, Kuhn S, Vorgias CE. The interaction in vitro of the intermediate protein vimentin and naturally occurring RNAs and DNAs. $J$ Biol Chem 1984;258:1456-66. 